Journal of Social Sciences 4 (1): 10-15, 2008

ISSN 1549-3652

(C) 2008 Science Publications

\title{
The Private Sector's Role in limiting unemployment in Jordan
}

\author{
Khaled M.M.Abu Aliqah \\ Tafila Technical University \\ P.O.Box 179, Tafila, 66110, Jordan
}

\begin{abstract}
This study is aimed to define unemployment, and private sector, to know more about both, and to study the role of the private sector in limiting unemployment in Jordan in special. In a particular year the level of unemployment is determined by the level of aggregate demand for the goods and services which a country produces .if demand higher this reduces unemployment so the demand side approach to unemployment .so to expand demand through higher budget deficits and lower interest rates. But unfortunately unemployment cannot be reduced indefinitely by expand demand .for eventually the economy will run into bottle necks and labor shortage that point employers will increasingly raise wages to attract labor and there will all be increased union demands for higher wages .so demand will have to stop rising-either of its own or through policy action. Thus our ability to reduce unemployment is limited by the labor shortages which begin to appear as unemployment falls are features of the "supply-side of the economy and it is they which determine how unemployment can fall without creating inflationary pressures while demand management is important the key issue for employment policy is how reduce the level of unemployment at which inflationary pressures appear.
\end{abstract}

Key words: Unemployment, private sector, Jordan, limiting unemployment

\section{INTRODUCTION}

Unemployment as mentioned by Abd Al-Qader, 2003 shall not stay a hidden danger but it becomes truly a direct danger threatening the social stability and peace for what it have of dangerous negative dimensions on the economical, societal, and political levels! Whatever figures and data conflicts, it warn crises and a catastrophic matters to be happen unless governments cooperated with private sector, international and local organizations do take practical solutions for facing it. ${ }^{[1]}$ Unemployment in economy: It is the case when an individual or a group can work, able to work, want to work, but cannot find work, or the conditions of work does not suits him/her or them.

We find also from Abd Al-Qader: Unemployment, 2003 that unemployment is a case of no work available to a person wants to work with his ability on it in a profession suitable with his abilities and preparations due to the work market situation. It is assumed not a case of unemployment the cases of strikes, sicknesses or injuries. Also unemployment defined as the case of the unemployed persons' existence that are able to work, wants to work, looking for work, but do not find $\mathrm{it}^{[2]}$.
Also from the same source: The unemployment assumed an increase in the labor forces looking for work larger than the works' opportunities that the society allows in all its various institutions. And the employee does not work event that he is able to work, looking for work and, does not find it. What is meant by unemployment is the people who do not work but they are available to work and looking for $\mathrm{it}^{[3]}$.

The unemployed according to Unemployment in Jordan: Dimensions and expectations: 1992, that the unemployed is defined as the person aged between 15-65 years old and does not work, even that he is able to work and wants to work and looking for it in a positive way through the supported time period and that is the week earlier than the interview day ${ }^{[4]}$.

From Oxford dictionary: 2000, we can fine that unemployment is the situation of being unemployed, if a factory closes, many people face unemployment. And on the word phrase unemployed we find not having a job, out of work, the people who do not have a job. ${ }^{[5]}$ Noting that as it seems the authors of the dictionary did not differentiate between the usage of job and the usage of work knowing that some uses the word job in a bad manner especially in America.

From Atlas Dictionary, we can find the definition for unemployment that it is ${ }^{[1]}$ not using the matter, ${ }^{[2]}$ The number of unemployed workers whom they are

Corresponding Author: Khaled M.M.Abu Aliqah, Tafila Technical University, P.O. Box 179, Tafila, 66110, Jordan 
counted mostly as a ratio of the total working force ${ }^{[6]}$. Bearing in mind that the word idiom unemployment is the reverse word to the idiom employed or employment. On the other hand, Private Sector is defined as the sector holding companies owned by individuals, groups, shareholders made from citizens and/or foreigners but not the government, the state or the country. There might be a case of course when the owner of a company is a mixture between the two, i.e. the government and the individuals. But on the contrary, the private sector is the reverse word to the public sector.

Knowing more about unemployment: The concept of unemployment holds part in some knowledgeable branches like economy, statistic, and sociology. The word unemployment must be dealt with apart of its definition with its kinds, ways of measuring it, its specialties and reasons.

\section{Kinds of unemployment:}

A- Below are some of one type of the kinds of unemployment:

- Veiled Unemployment: It means that there are many workers working in productive activities that it is possible to pull them out without any change in total results. This happen a lot in the industrial sector and many governmental directorates suffers from it because of the obligation of the governments to employ the graduates. It is possible to say that the veiled unemployment is the case when the marginal product for the worker equals zero or negative or very little. In fact the idiom Veiled Unemployment describes cases adjacent with the depression periods in the industrial countries or growing periods in the developing countries.

- Seasonal or chosen unemployment: It means that the work is not organized or not continuous for sample of young people and aged people in special seasons like what is going on in agricultural sector when really there is a gap between one harvest and the other. This may lead to the transfer of the worker suffering unemployment to the cities which may lead to pressure on residents and services.

- Periodical unemployment: This kind of unemployment spreads in the developed capital countries when its national economy suffer crises resulting from decrease of the real demand and that may lead to stop to a large side of the productive energy of the national economy. Then this leads to unemployment between workers. The influence of these crises has dangerous impacts on the economics of these countries.

- Unconcealed unemployment (Clear, forced and open): It means the existence of number of people [males and females) ready to work and there aren't working opportunities inside the economical institutions. This kind of unemployment is familiar and do exist. It happens as a result of shortage of demand on working hands especially in productive sectors [not agricultural) like industrial and some services needing large capitals.

The following samples are excluded from unconcealed [open or clear) unemployment: all children less than special age for work, old people higher than special age of work, also those who are not able to work completely, the people who are delayed from entering the work market like students, pregnant women, and prisoners. Also the foreigners and strangers are excluded. The unconcealed forced unemployment a situation of sickness inside the economical structure and it is a pointer for the decrease ability of such economy to hold and contain the work factor. It also means a working surplus inside the economical structure of the society and that there isn't balance between the available working force and between the work opportunities available inside society.

B- Other type of other kinds of unemployment: There are many kinds of unemployment between veiled ones and clear ones. In fact the specialists take the unemployment kinds and divide them into another division to:

- Building unemployment: It is the one that result as a shortage in the economical structure, from changes or from disorder inside it. Also as a result of many factors affecting the economy and making it grow in a slow average to make working opportunities available compared to the fast growing average of new people entering the working force. This is as close as ever to clear unemployment.

- Frictional unemployment: It represents a small ratio of the work force when this ratio is in an unemployment situation because of time factor. This applies in transferring graduates from schools and universities to be employed or a delay period between leaving an employment to join another. This kind of unemployment is not because of a 
default in securing employments and works, and might be not a problem at all. But some of those under this category may register his/her name under those who want to be employed and thus affecting the working force. This applies also on countryside immigrants who leave the agricultural activities and services and goes to the big cities and urban centers so as to have more suitable opportunities better from their points of views from the former ones. This also has its impact on working force in the city.

- Technological Unemployment: This appears because of putting the machine instead of the worker. What some calls it mechanism, like what happen in agricultural projects when new machines is been put instead of the working hands. This is called Technological Unemployment as a result of using new technology which may lead to increasing the agricultural unemployment size. ${ }^{[7]}$

Ways of measuring In general: According to what Abd A;-Qader, 2003 is talking about, the normal changes that happen in production and working forces instruments must make a little unemployment even if the national economy is in a case of marketability and prosperity. The economy in its self forces prevents the average size of such unemployment from getting bigger.

This average of unemployment might represent a problem from an economical point of view, but even this little average, it still possible that it makes a problem from social point of view, especially if the unemployment period were long for some workers.

There are many ways one can count through them the unemployment ratio, and these vary between one society and another, and it represent the following:

First: The census procedures and sources.

Second: Sample's working forces' researches: These are issued through some ministries and some directorates. It is noted that the census procedures are more general and might be misleading while the figures from the special directorates concerned about such matters are on yearly bases but they have a failure point of the change of the samples.

Another way is to measure the unemployment as an average of unemployed workers against the whole number of citizens in a special country or nation, or against the working force in another country or nation. Obviously, the average is less when compared to the whole citizens than to the working force, because working force is just a partial number of the whole number of citizens. ${ }^{[8]}$
To shape and construct the equations for that, it is clear that:

$$
\begin{gathered}
\text { Average ratio of } \\
\text { unemployment }
\end{gathered}=\frac{\text { No.of unemployment }}{\text { Whole number of citizens }} \times 100 \%
$$

Or:

Average ratio of
unemployment $=\frac{\text { No.of unemployement }}{\text { Whole number of working force }} \times 100 \%$

And in many developing countries and as there aren't enough statistical information available on citizens and working forces, the unemployment size measured through absolute figures or by pointing the increase to the total unemployment size. Depending on the fact that if registered statistics on unemployment, number of citizens and working force are not that neat, then it isn't that important if the unemployment were measured in this or that method.

In fact the unemployment measurement depends on some ruling international definitions decided in each of:

Working force: This means the people between 15-65 of age subtracting from them students, those who do not work because they have another source of life so they do not want to work and housewives whom assumed internationally as not paid labor.

Unemployment size: The international definition is the sum of all of those who fall under these three categories: able to work, looking for a working opportunity, and do not find it.

Unemployment counting: By subtracting the really working from the whole number of working force. In deciding who are really accepted to enter the unemployment case, Abd Al-Qader, 2003 mentions in his book that three kinds of graduates are usually taken away from being unemployment. These are those who wants to work but unable to do so, those who want to work but do not like to work in such work, and those who work and wants to change the special work he/she are under, either because It is a seasonal work or because he does not like what he gain from it. The case crystallize in graduates unemployment really for those who wants to work, able to do it, looking for it, and do not find $\mathrm{it}^{[9]}$

For the private sector: For the private sector we can measure unemployment in a little bit of difficulty because private sector in itself is a part of the whole economical structure for a nation or a country. 
We can however put the following equation as estimations:

\author{
Average ratio of \\ unemployment $=\frac{\text { No. of unemployment }}{\text { Whole number of citizens }} \times 50 \%$
}

Average ratio of unemployment depending on private sector

$$
\begin{gathered}
\text { Average ratio of } \\
\text { unemployment }
\end{gathered}=\frac{\text { No.of unemployment }}{\text { Working force }} \times 50 \%
$$

Assuming that private sector is activating as half the national economy's activities.

Of course we can find better results in knowing the exact figure the private sector fills from the whole national economy. Then we can apply either Equation. 3 and/or 4.

Reasons for unemployment in Jordan: From unemployment in Jordan we can find out the following: It is not that easy to identify a special reason for unemployment. It is a reason for many factors activated between each others like economical, social, and political conditions reflecting on the labor market and makes in it some gapes between demand and supply.

There are two main factors that govern this problem:

- General Reasons.

- Objective Reasons.

- General Reasons.

There are some internal and external reasons that have a clear effect in the existence of the unemployment problem. One of these effects is the economical stagnancy which affects the whole region in general and Jordan in special.

Internal reasons: The slow movement of growth in economical activity, the rise of demographic growth in Jordan, the increase of graduates according to the teaching system, and the flow of foreign work force are the main reason in limiting the ability of the Jordanian work force to contain the supply work force and the making of new working opportunities.

On the demand side on labor force, the slow movement of the economical activity had the large effect in preventing the national economy manage to contain the supply of the labor force through not being able to establish necessary working opportunities.

On the supply side, the rise of the average demographic growth in Jordan, which was estimated to be $3.6 \%$ yearly during the period 1986-1991 and estimated to be $12 \%$ yearly through the period 1990-1991 due to the return of at least 300 thousand citizen to Jordan because of the Gulf Conflict led to the increasing number in working labor force. Also the increasing numbers of graduates which reached from 12.5 thousand graduates for the academic year 19851986 to nearly 19.5 thousand graduates for the academic year 1990-1991 in a yearly increasing average of $11.3 \%$. That led to the increasing of supply of working labor force in a highly manner. ${ }^{[10]}$

Also there are the problems and/or solutions of the flow of foreign working forces. One can see that it is a large solution from one side point of view, yet on the other side some of its effects might lead to problems.

External Reasons: These can be summarized as follows:

- The economical stagnancy which affected the Arab region since the beginning of the eighties of the 20 th century.

- The external demand retreat on Jordanian working force in the oil countries because of what's going on in them. Also many of these countries started replacing local working force instead of Jordanian labor. Also these countries finished many of the infrastructure and growth projects. So all of these reasons led to decreasing number of Jordanian immigrating to work in these countries. This led to decreasing the size of transformations of money from Jordanians working in the Gulf States. This number decreases from 10-12 thousand worker yearly between 1973-1983, to about 4-8 thousand worker yearly during 1984-1988. The transformation of money from those working abroad decreases from 1184.2 million dollar in 1986, to what was estimated to be 524.2 million dollar in 1990. All of this above assisted increasing the supply of labor force in Jordanian labor market $^{[1]}$. So how much the figure is now depending on these figures on one side and the real figures from real statistics and measurements?

- Gulf conflict and what happened because of it to many Jordanians and many others.

\section{Objective reasons:}

- Reasons of not getting work.

- Reasons of loosing [leaving) work. "[12]

The privatization and unemployment:

Private sector special kind and unemployment, Jordan as an example: There are some procedures in the whole operation of privatizations and denationalizations concerning unemployment in Jordan, some of them were: 
- Guarantee justice and continuation for some employees holding efficiencies, paying compensations to others whom been taken out. Some agreements with the local and foreign investors contained conditions obligate the investor to keep the employees for one or two years or compensate them.

- Finding new opportunities of work in other position.

- Preparing training programs and courses to rehabilitate the fired workers in other works.

- Giving the employees and workers the priorities in owning a ratio from the projects and institutions' shares that are privatized.

- Financing some economically proved to be good projects especially those having employment densities so as to take as many of them as possible.

- Paying compensations and rights to the employees and workers because of transforming them from public institutions to privatized now private companies.

- Finally, in this category, not touching the gained tights and retirements rights through the operations of buying the service and working years from the Social Security.

The privatization law No. (25) for the year 2000 points out this subject in clause [D/5 and 6) from article (13) that there is a usage of part of the privatization yields to rehabilitate and train the workers in institutions and committees that been reconstructed and privatized. Also there is settlements to their financial rights against these bodies and the buying of the serving working years for the employees in the institutions that been privatized whom they shall be under the social security law.

What happened really is that the information available leads to the fact that there were training for workers used to be in such privatized and denationalized institutions. Many of these workers stayed in such projects in some cases, in other cases they have been given to other new working opportunities especially those of the same nature to their specialties. An example for that is Royal Jordanian whom been transformed to Tourism and travel sector. As Kindah, 2003 says, there were compensations for others and a saving for their rights and gaining. In fact some of the workers in Aqaba railways were been transformed to other working places in better conditions. $^{[13]}$

The need for training for the unemployed, with a relation somehow with private sector: Through what Unemployment in Jordan book is saying, the results of
Table 1: Distribution of suggested projects according to their numbers, cost, and estimated costs $(1991)^{*}$

\begin{tabular}{|c|c|c|c|}
\hline The project domain & Numbers & Cost in JD & $\begin{array}{l}\text { Average } \\
\text { cost in JD }\end{array}$ \\
\hline Trading & 366 & 2747900 & 7508 \\
\hline Agricultural & 125 & 1123300 & 8986 \\
\hline Trecco tailor workshop & 120 & 471100 & 3926 \\
\hline Supermarket [Grocery) & 94 & 450000 & 4787 \\
\hline Buy a taxi car & 94 & 1029200 & 10949 \\
\hline Garage for repairing cars & 52 & 318300 & 6121 \\
\hline $\begin{array}{l}\text { Engineering and } \\
\text { consultation office }\end{array}$ & 27 & 258300 & 9567 \\
\hline Drainage and electricity & 31 & 161500 & 5210 \\
\hline $\begin{array}{l}\text { Boilers maintenance } \\
\text { and services }\end{array}$ & 30 & 169300 & 5643 \\
\hline Aluminum blacksmith & 19 & 126500 & 6658 \\
\hline $\begin{array}{l}\text { Marketing, and } \\
\text { advertisement office }\end{array}$ & 12 & 110000 & $9167 \backslash$ \\
\hline Schools, and nurseries & 39 & 405000 & 10385 \\
\hline Hairdresser & 55 & 169600 & 3084 \\
\hline Restaurant & 19 & 132500 & 6974 \\
\hline Bakery & 6 & 16200 & 2700 \\
\hline Tourist and airlines office & 6 & 86000 & 14333 \\
\hline Opening a factory & 12 & 128000 & 10667 \\
\hline Floor tile factory & 6 & 29000 & 4833 \\
\hline Calligrapher & 3 & 11000 & 3667 \\
\hline Medical labs & 12 & 136000 & 11333 \\
\hline $\begin{array}{l}\text { Educational teaching } \\
\text { centers }[\text { Secretary and } \\
\text { computers ...etc) }\end{array}$ & 12 & 47500 & 3958 \\
\hline Electrical devices reparations & 10 & 45000 & 4500 \\
\hline Carpenter shop & 10 & 87500 & 8750 \\
\hline Shoes maker & 2 & 9000 & 4500 \\
\hline Photography shop & 3 & 10000 & 3333 \\
\hline Sport club & 4 & 40000 & 10000 \\
\hline Insurance office & 1 & 10000 & 10000 \\
\hline Total & 1170 & 8327700 & 7118 \\
\hline
\end{tabular}

scanning in a former period showed that $55.8 \%$ from the answers of unemployed amounted to 6931 answers pointed out to the need of training, compared to $28.6 \%$ of answers said that it is not necessary. The rest of the answers said that there are no differences in training and/or not training. For those who answered that they do not need new training, it seems either they hold a former profession and have some experience in it or the nature of work asked about does not need training. For those who answered that there are no differences, it is possible to explain that that they do not know the nature of the work they are asked about, so they did not manage to decide whether they need training or not.

So to summarize the policies to limit unemployment whether in general and/or through private sector we can note the following:

- The government pays special attention to the unemployment problem through issuing following policies and legislations to find the suitable solutions for the unemployment problem. 
- The unemployment suggestions concentrated in finding work opportunities, establishing new projects.

- 1170 unemployment person different types of projects summarized in table No. [1) below.

- There was a question whether the unemployment person needs training or not. ${ }^{[14]}$

From Table 1, we can notice the private sector's role in many of them:

\section{CONCLUSIONS}

One of the main problems is the case of unemployment which faces a bad solutions to it. Let's take for example the construction and building of Suwais Channel. When the project was tried to be done, the French and English company, headed by De Lesipse as the manager engineer or something tried to use and force thousands of Egyptians and may be others to work in the digging and excavation procedures through what is called work by corves or forced labor. History tells us that many of those workers died in a very badly situations. Well, was not this assumed a way to cover unemployment problem? Was not the company assumed part of private sector and/or also a foreign private sector? But the true facts appear later that the workers were in reality never paid their rights. So, unless there are real good justifications and vindications to the matter, then there happen on the faces of both history and geography and other subjects a large fraud starting from the point of not paying the workers their rights. On the other hand, private sector in developed countries play a main essential role in letting thousands and million of workers working in what are assumed a very good working conditions.

Let's take an example of those assumed highly qualified people who graduate every year from universities and high schools and eager to enter the working force markets. If there are coordination and harmonization between the needs of the private sector and the study's curriculums in such places of teaching, then the graduate shall have a better opportunity not to enter at least what is called above in this research frictional unemployment, or decreases it as much as possible. By subtracting the real working force from the total capable working force or through other ways to know the exact numbers of unemployment in a special society, country and/or nation then the plans can go further in allocating the works for those who suffers unemployment. Yet there are some negative signs of this, that is the existence of bad people, like the owner of an enterprise or who does not knows at all, the lack of trust between a foreign investor and a local society, and the tendency for some private sector's owners to only letting his/her family in the work ... etc. All of that was assumed talking from the true justified valid correct point of opinion and view.

The last point to be mentioned in the conclusions and recommendations section is that one of the ways to improve the private sector's role in limiting the unemployment in Jordan is by solving the private sector's problems. This may be done from the primitive point of view and primitive study of making the decision of do we depend on the management and decision making of private sector on the one person management experience or improve that, also do we stay as small institutes for many of the private sector companies, widen, and/or make the company smaller. By solving such problems we can find some solutions to the unemployment problem altogether through for example the going to be needs of more employments and the like ${ }^{[16]}$

\section{REFERENCES}

1. Bruno, Frank 1998 The Front Collin Virtual Business Incubator, public Management, 80 (3), 10-13

2. Dr. 'Adli Shehata Kindah. Privatization, the newest economical growing samples, $1^{\text {st }}$ ed., 2003, 1424, Majdalawi Pub. \& Dis., Amman-Jordan.

3. Atlas Dictionary, English-Arabic, Atlas Publishing House, $1^{\text {st }}$ ed. Egypt, 2002.

4. Dr. Mohammad Ala' El Dien Abd Al-Qader, 2003. Unemployment, Al-Ma'aref Inst., Alexandria

5. Dr. Mohammed Sa'ad Omerah et al, 1992. Unemployment in Jordan, Dimensions and expectations, International Studies Center, Royal Scientific Society, Jordan.

6. Oxford Dictionary, English-English-Arabic, Oxford University Press, Fifth impression, China, 2000.

7. 7- Unemployment, Dr. Mohammad Ala' El Dien Abd Al-Qader, Al-Ma'aref, 2003. Inst., Alexandria, from the preface.

8. 8- Atlas Dictionary, English-Arabic, Atlas Publishing House, $1^{\text {st }}$ ed. Egypt, 2002, p. 1399.

9. 9- Adli Shehata Kindah, Privatization, the newest economical growing samples, $1^{\text {st }}$ ed., 2003, 1424, Majdalawi Pub. \& Dis., Amman-Jordan, pp. 134135 . 